\title{
Changes in the protein content of mouse uterine flushings during normal pregnancy and delayed implantation, and after ovariectomy and oestradiol administration
}

\author{
R. J. Aitken* \\ Department of Genetics, University of Edinburgh, U.K.
}

\begin{abstract}
Summary. The protein content of the mouse uterine lumen increased significantly $(P<0.001)$ on Day 4 of pregnancy, the day of implantation. This increase was associated with the presence of 14 serum and 22 non-serum proteins in the lumen; the major serum proteins were classed as high molecular weight slow $\alpha$-globulins, while the dominant non-serum components consisted of slow and fast $\alpha$-globulins, 6 prealbumins and a large quantity of proteinaceous material migrating near the origin of the gels.

During experimental and lactational delayed implantation the protein levels were constantly low, transferrin, haemoglobin and albumin dominating the protein pattern. After administration of oestradiol-17 $\beta$, however, a biphasic uterine response was detected, significant increases in luminal protein concentration being observed within $12 \mathrm{~h}$ and again at $40-48 \mathrm{~h}$ after injection. The first phase of this response involved an influx of serum and non-serum proteins into the uterine lumen, most proteins migrating as high molecular weight slow $\alpha$-globulins. The second phase involved an increase in the intensity of many non-serum components, the major proteins having $R a$ values of $0 \cdot 06,0 \cdot 10$ and $0 \cdot 32$. The qualitative, but not the quantitative, aspects of this response to oestradiol were identical in the absence of blastocysts.
\end{abstract}

\section{Introduction}

During normal pregnancy in the mouse the morula-blastocyst transition is associated with a sudden increase in embryonic activity (Mills \& Brinster, 1967; Woodland \& Graham, 1969; Menke \& McLaren, 1970; McLaren \& Menke, 1971; Weitlauf, 1971; McLaren, 1973), culminating in the initiation of implantation at about $93 \mathrm{~h}$ post coitum (Finn \& McLaren, 1967). If pregnancy is accompanied by lactation, however, these changes do not occur (Weitlauf, 1971; McLaren, 1973) and the blastocysts enter a period of embryonic diapause or delayed implantation. A similar state of diapause can be induced experimentally by ovariectomizing mice on Day 2 of pregnancy and subsequently administering progesterone (Yoshinaga \& Adams, 1966). Lactational and experimental diapause can be terminated by the injection of a small dose of oestrogen (Yoshinaga \& Adams, 1966; McLaren, 1968; Nalbandov, 1971). The way in which the uterus alternately suppresses and stimulates embryonic activity is not known, but two hypotheses have been put forward: (1) that the uterus elaborates an inhibitor during diapause which is withdrawn in response to oestrogen stimulation, and (2) that oestrogen induces the release of an embryotrophic secretion which is absent during delayed implantation.

The purpose of the present study was to examine the proteins present in the mouse uterine lumen during normal pregnancy, delayed implantation and following the administration of oestradiol in the hope of detecting changes that might be associated with the activation or suppression of embryonic activity.

* Present address: M.R.C. Reproductive Biology Unit, 39 Chalmers Street, Edinburgh EH3 9ER, U.K. 


\section{Materials and Methods}

Animals. Female mice of the randomly bred $\mathrm{Q}$ strain were placed with intact or vasectomized males and examined daily; the day on which a vaginal plug was found was designated as Day 0.

Induction and termination of delayed implantation. Delayed implantation was induced experimentally by ovariectomizing mice on Day 2 of pregnancy or pseudopregnancy and administering $1 \mathrm{mg}$ medroxyprogesterone acetate (Depo-provera: Upjohn), a long-acting progestin. Lactational delayed implantation was induced by mating females at the post-partum oestrus and adjusting the litter number to a minimum of 6 young. Experimental delayed implantation was terminated within 7 days by the administration of $1 \mu \mathrm{g}$ or $50 \mathrm{ng}$ oestradiol-17ß (Sigma), both doses proving highly effective in the initiation of implantation (Humphrey, 1967).

Collection of uterine flushings. Uterine flushings were collected between 10.00 and $16.00 \mathrm{~h}$ on Days 2, 3 and 4 of normal pregnancy, Days 4, 5, 6 and 7 of pregnancy concurrent with lactation, Days 5, 7 and 9 of experimental delayed implantation and at selected time intervals after the administration of oestradiol. Uterine flushings were also collected from non-pregnant mice which had been ovariectomized at least 8 days previously. The uteri were carefully removed from mice killed by cervical dislocation and placed on cold damp filter paper. The uterine horns were cleared of adhering mesentery, separated and blotted gently to remove all trace of blood. Each horn was flushed rapidly

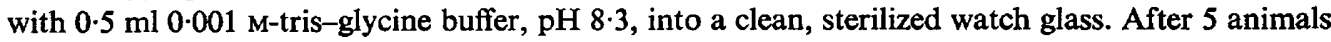
had been treated in this manner in quick succession, the flushings were pooled, centrifuged at $2000 \mathrm{~g}$ for $20 \mathrm{~min}$, frozen to $-90^{\circ} \mathrm{C}$, freeze dried and finally redissolved in $100 \mu \mathrm{l}$ double-distilled water.

Chemical analysis. The protein content of the flushings was estimated for 30- $\mu 1$ samples by the technique of Lowry, Rosebrough, Farr \& Randall (1951). To compensate for the inhibitory effect exerted by glycine on the colour development of the Folin-Ciocalteu reagent, tris-glycine buffer was also incorporated into the BSA standards.

Qualitative analysis of the uterine proteins was carried out on $70 \mu \mathrm{l}$ samples using $7 \%$ polyacrylamide gels, pH 8.9 (Davis, 1964).

The significance of the means was assessed by Student's $t$ and Mann-Whitney tests.

\section{Quantitative analysis \\ Results}

Quantitative analysis of the uterine flushings revealed a highly significant $(P<0.001)$ increase in protein concentration on Day 4 of pregnancy, the day of implantation. In contrast, the protein content of the uterine flushings was uniformly low following ovariectomy and the induction of experimental or lactational delayed implantation (Table 1).

The administration of oestradiol-17 $\beta$ to pregnant animals during experimental delayed implantation elicited a biphasic pattern of protein release into the uterine lumen (Table 2). With the $1 \mu \mathrm{g}$ dose, significant increases in uterine protein concentration were observed at $4-6 \mathrm{~h}(P<0.005)$ and 40-48 h $(P<0.001)$ after injection; similar changes were observed $12 \mathrm{~h}(P<0.005)$ and $40-48 \mathrm{~h}$

Table 1. Changes (mean \pm S.D.) in the protein content of mouse uterine fiushings during pregnancy, delayed implantation and after ovariectomy

\begin{tabular}{|c|c|c|c|c|c|c|c|}
\hline & \multicolumn{3}{|c|}{ Day of pregnancy } & \multicolumn{2}{|c|}{$\begin{array}{l}\text { Experimental delayed } \\
\text { implantation }\end{array}$} & \multirow{2}{*}{$\begin{array}{l}\text { Lactational delayed } \\
\text { implantation }\end{array}$} & \multirow[b]{2}{*}{ Ovariectomy } \\
\hline & 2 & 3 & 4 & Pregnant & Pseudopregnant & & \\
\hline $\begin{array}{l}\text { Conc. of protein } \\
\text { ( } \mu \mathrm{g} / \text { mouse) }\end{array}$ & $\begin{array}{r}4.5 \\
\pm 1.4\end{array}$ & $\begin{array}{r}4 \cdot 8 \\
\pm 2 \cdot 2\end{array}$ & $\begin{array}{r}19 \cdot 9 \\
\pm 3 \cdot 8\end{array}$ & $\begin{array}{r}6.9 \\
\pm 1.2\end{array}$ & $\begin{array}{r}6 \cdot 3 \\
\pm 1 \cdot 2\end{array}$ & $\begin{array}{r}3.8 \\
\pm 0.7\end{array}$ & $\begin{array}{r}3.3 \\
\pm 1.9\end{array}$ \\
\hline $\begin{array}{l}\text { No. of mice } \\
\text { ( } 5 \text { mice/sample) }\end{array}$ & 10 & 40 & 35 & 40 & 15 & 25 & 20 \\
\hline
\end{tabular}


$(P<0.025)$ after the administration of $50 \mathrm{ng}$ oestradiol-17 $\beta$. However, the injection of oestradiol-17 $\beta$ into ovariectomized pseudopregnant mice did not induce any significant increases in luminal protein content (Table 2).

Table 2. Changes (mean \pm S.D.) in the protein content of uterine flushings after injection of oestradiol-17 $\beta$ to ovariectomized pregnant or pseudopregnant mice treated with a progestin (i.e. delayed 'implantation')

\begin{tabular}{|c|c|c|c|c|c|}
\hline \multirow[b]{2}{*}{$\begin{array}{l}\text { Oestradiol } \\
\text { dose }\end{array}$} & \multirow{2}{*}{$\begin{array}{c}\text { Time } \\
\text { after } \\
\text { oestradiol } \\
\text { (h) }\end{array}$} & \multicolumn{2}{|c|}{ Pregnant mice } & \multicolumn{2}{|c|}{ Pseudopregnant mice } \\
\hline & & $\begin{array}{c}\text { Conc. of } \\
\text { protein } \\
(\mu \mathrm{g} / \text { mouse })\end{array}$ & $\begin{array}{l}\text { No. of mice } \\
\text { (5/sample) }\end{array}$ & $\begin{array}{c}\text { Conc. of } \\
\text { protein } \\
(\mu \mathrm{g} / \text { mouse })\end{array}$ & $\begin{array}{l}\text { No. of mice } \\
\text { (5/sample) }\end{array}$ \\
\hline \multirow[t]{9}{*}{$1 \mu \mathrm{g}$} & $\begin{array}{l}0 \\
1\end{array}$ & $\begin{array}{l}6.9 \pm 1.2 \\
7.2 \pm 1.4\end{array}$ & $\begin{array}{l}40 \\
15\end{array}$ & $6.3 \pm 1.2$ & $\frac{15}{-}$ \\
\hline & 2 & \pm & 10 & $6.5 \pm 1.0$ & $\overline{15}$ \\
\hline & 4 & $10 \cdot 5 \pm 1.7$ & 15 & $7 \cdot 4 \pm 1 \cdot 3$ & 15 \\
\hline & 6 & $8.5 \pm 0.8$ & 15 & $7.5 \pm 0.5$ & 15 \\
\hline & 12 & $6.1 \pm 0.8$ & 15 & $4.9 \pm 2.8$ & 15 \\
\hline & 24 & $7.5 \pm 1.6$ & 15 & $6.0 \pm 0.4$ & 15 \\
\hline & 40 & $12 \cdot 8 \pm 2 \cdot 3$ & 15 & $4.4 \pm 0.7$ & 15 \\
\hline & 44 & $11.0 \pm 4.2$ & 10 & = & - \\
\hline & 48 & $14 \cdot 6 \pm 4 \cdot 5$ & 20 & $5 \cdot 4 \pm 2 \cdot 6$ & 20 \\
\hline \multirow[t]{7}{*}{$50 \mathrm{ng}$} & 0 & $6.9 \pm 1.2$ & 40 & $6 \cdot 3 \pm 1 \cdot 2$ & 15 \\
\hline & 3 & $5 \cdot 3 \pm 0 \cdot 2$ & 10 & $6 \cdot 5 \pm 2 \cdot 4$ & 10 \\
\hline & 6 & $5.4 \pm 0.2$ & 10 & $3.6 \pm 1.0$ & 10 \\
\hline & 12 & $10.9 \pm 1.1$ & 10 & $2.3 \pm 0.7$ & 10 \\
\hline & 24 & $4 \cdot 3$ & 5 & $4 \cdot 4 \pm 1 \cdot 1$ & 10 \\
\hline & 40 & $10 \cdot 1 \pm 4 \cdot 3$ & 10 & $4.2 \pm 0.5$ & 10 \\
\hline & 48 & $13 \cdot 3 \pm 7 \cdot 5$ & 10 & $5 \cdot 4 \pm 2.0$ & 10 \\
\hline
\end{tabular}

\section{Qualitative changes}

In the following section, the proteins are described as $\alpha$ - or $\beta$-globulins (Cons $\&$ Glass, 1963), or according to their relationship with serum transferrin and albumin (Text-fig. 1).

Transferrin, albumin and haemoglobin. Serum transferrin (transferrin 3, genotype $\operatorname{Tr} \mathrm{f}^{\mathrm{b}} / \operatorname{Tr}^{\mathrm{b}}$; Renfree \& McLaren, 1974) and albumin were observed in all the uterine flushings examined. Albumin appeared as a single quantitatively dominant band or occasionally as two bands running in close proximity. A double albumin band has also been observed following the electrophoresis of rat blood plasma (Beaton, Selby \& Wright, 1961) and its appearance in the present study did not appear to be related to the physiological state of the animals. Since the flushing medium used was hypotonic to serum, most of the flushings examined also contained prominent haemoglobin bands. The $Q$ strain segregates for both $\mathrm{Hbs}$ and $\mathrm{Hbd}$ forms of mouse haemoglobin, giving a maximum of 4 protein bands in the pooled samples. Two dominant proteins $(R a 0 \cdot 60,0 \cdot 63)$ corresponded with the monomers designated $\mathrm{Hb}_{2}$ and $\mathrm{Hb}_{3}$ by Morton (1966), while two minor components $(R a 0 \cdot 57,0 \cdot 68)$ resembled $\mathrm{Hb}_{\mathbf{1}}$ and $\mathrm{Hb}_{5}$ of Morton's classification.

\section{Days 2, 3 and 4 of pregnancy}

With the exception of a major, non-serum, slow $\alpha$-globulin (Ra 0.06) observed on Day 2 , transferrin, haemoglobin and albumin dominated the protein profiles on Days 2 and 3. On Day 4, however, a large number of intense protein bands were observed, of which the most significant were 2 slow $\alpha$-globulins $(R a 0 \cdot 16,0.20)$ and a fast $\alpha$-globulin $(R a 0.74)$ of serum origin, and 22 non-serum components comprising 8 slow $\alpha$-globulins (major proteins having $R a$ values of $0 \cdot 06,0 \cdot 10,0 \cdot 25,0 \cdot 32$, $0 \cdot 34$ ), 4 B-globulins, 3 fast $\alpha$-globulins (major proteins having $R a$ values of $0 \cdot 82,0 \cdot 89$ ), 6 prealbumins (major proteins having $R a$ values of $1 \cdot 19,1 \cdot 31$ ) and a large quantity of proteinaceous material migrating near the origin of the gels behind the major serum lipoprotein band. The uterine proteins 


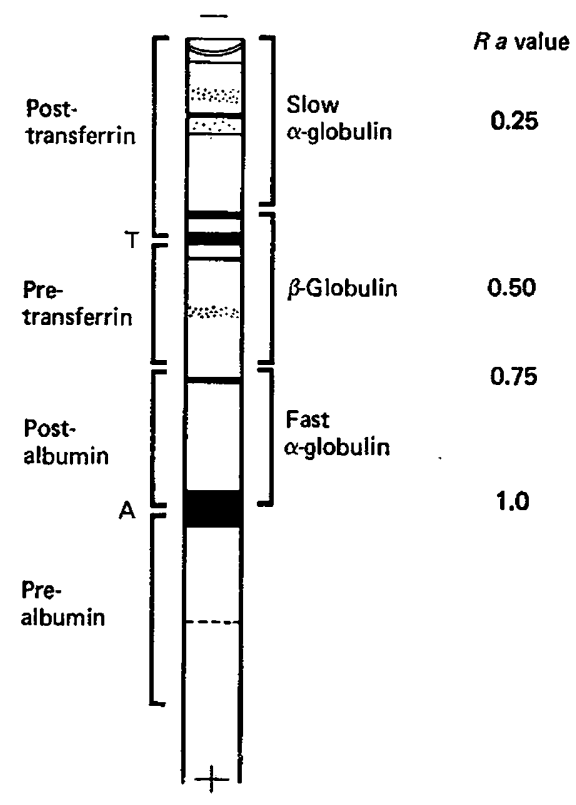

Text-fig. 1. Electrophoresis of mouse blood plasma to demonstrate the classification system used for describing proteins in this study. Proteins are characterized by their mobility relative to the centre of the albumin band ( $R a$ value; $R a$ albumin $=1 \cdot 0$ ). Regions of the gel are designated as slow $\alpha-$ globulin $(R a 0-0 \cdot 34), \beta-$ globulin $(R a 0.35-0.70)$ and fast $\alpha$-globulin $(R a 0.70-1.00)$. Alternatively, the gel may be divided into posttransferrin $(R a 0-0 \cdot 43)$, pre-transferrin $(R a 0 \cdot 43-0 \cdot 70)$, post-albumin $(R a 0 \cdot 70-1 \cdot 00)$ and pre-albumin $(R a>$ $1 \cdot 00$ ) zones. $T=$ transferrin; $A=$ albumin.

recovered on Day 4 were also characterized by the absence of one serum $(R a 0 \cdot 47)$ and 2 minor nonserum ( $R a$ 0.92, 0.94) components observed on Day 3 (Text-fig. 2).

\section{Delayed implantation}

During experimentally induced delayed implantation, 29-30 protein bands were consistently observed; 16 were not of serum origin. The protein profiles were dominated by transferrin, haemoglobin and albumin, the remaining proteins being present in trace amounts only. Qualitatively the delay pattern resembled that observed on Day 4 of normal pregnancy, although the concentration of high molecular weight proteins in the delay samples was seriously diminished. The protein profile observed during experimental delayed implantation did, however, feature one serum $(R a 0.47)$ and 2 non-serum $(R a 0.92,0.95)$ bands not visible on Day 4 (Text-fig. 2; Plate 1$).$

Lactational delayed implantation was also characterized by a lack of proteins in the high molecular weight region of the gels. A maximum of 37 bands were observed at this time, including 22 nonserum components, but once again transferrin, haemoglobin and albumin were the major proteins present (Text-fig. 2; Plate 1).

\section{Ovariectomy}

The weak protein pattern observed in ovariectomized non-pregnant mice was dominated by transferrin, haemoglobin and albumin bands, although traces of non-serum proteins were observed near the origin of the gels and in the prealbumin region (Text-fig. 2; Plate 1).

\section{Administration of oestradiol-17 $\beta$ during delayed implantation}

The elevated protein levels observed 4-6 h and $12 \mathrm{~h}$ after the administration of $1 \mu \mathrm{g}$ and $50 \mathrm{ng}$ oestradiol-17ß, respectively, were associated with a marked increase in the intensity of several non- 

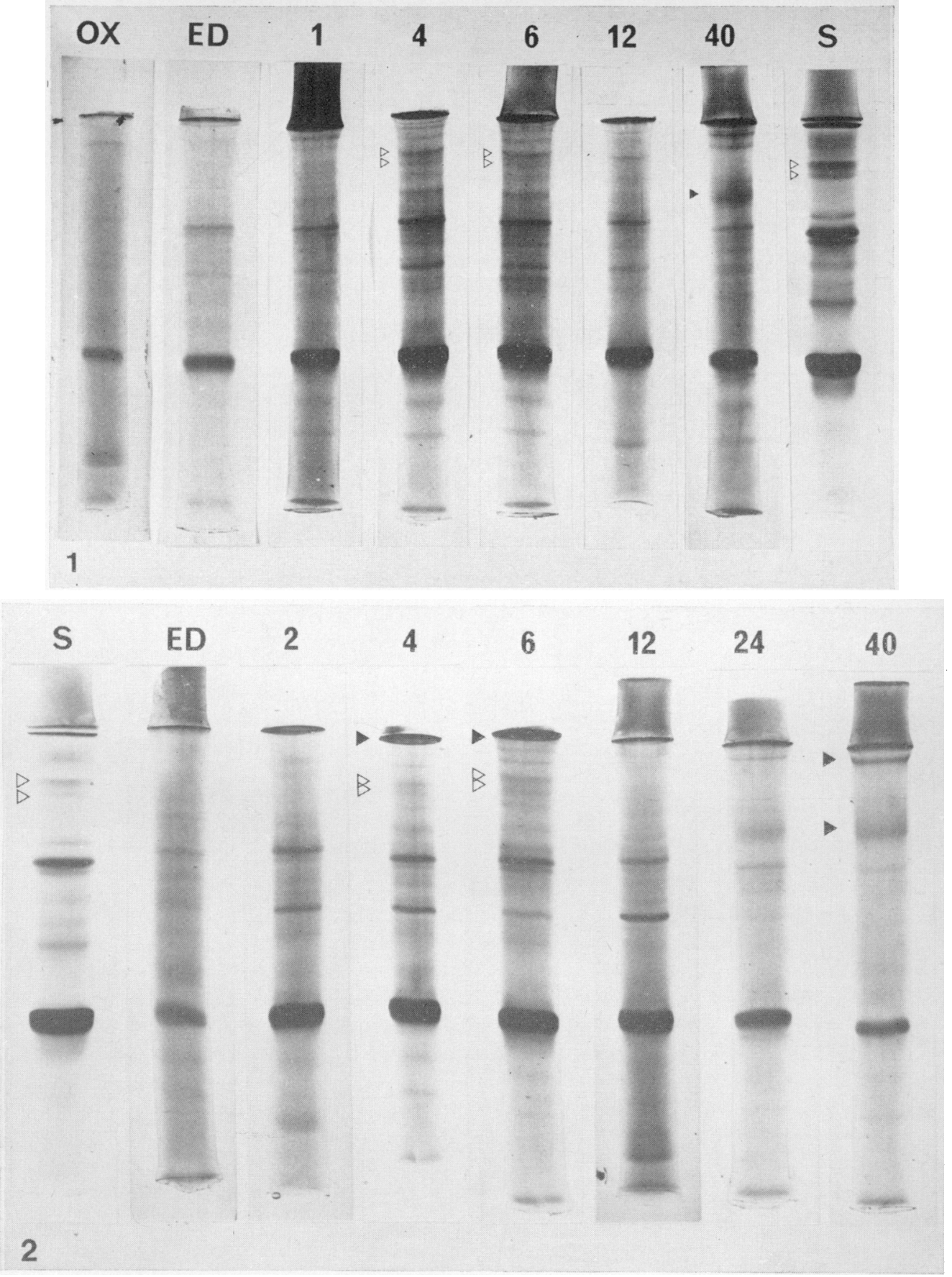

Polyacrylamide gel electrophoresis of the uterine flushings of ovariectomized pregnant (Fig. 1) or pseudopregnant (Fig. 2) mice after administration of $1 \mu \mathrm{g}$ oestradiol-17 $\beta$ (i.e. delayed 'implantation'). $\mathrm{OX}=$ ovariectomized animals; $\mathrm{ED}=$ experimental delayed implantation; $\mathrm{S}=$ serum $; 1,2,4,6,12,24$ and $40=\mathrm{h}$ after oestradiol administration. Note the pronounced increase in the number and intensity of bands 4-6 h after injection, the general decline in protein concentration at $12 \mathrm{~h}$ and the subsequent increase in nonserum proteins at $40 \mathrm{~h}$ (Fig. 1) and 24 and $40 \mathrm{~h}$ (Fig. 2).

Fig. 1. At $\mathrm{S}, 4$ and $6 \mathrm{~h}$, open arrows $=$ serum slow $\alpha$-globulins $(R a 0.16$ and 0.20$)$; at $40 \mathrm{~h}$, closed arrow $=$ major non-serum slow $\alpha$-globulin at $R a 0 \cdot 32$.

Fig. 2. At $S, 4$ and $6 \mathrm{~h}$, open arrows $=$ serum slow $\alpha$-globulins $(R a-16$ and $0 \cdot 20)$, closed arrows $=$ proteinaceous material at the origin; at $40 \mathrm{~h}$, closed arrows = major non-serumslow $\alpha$-globulins at $R a 0.06$ and 0.32 . 


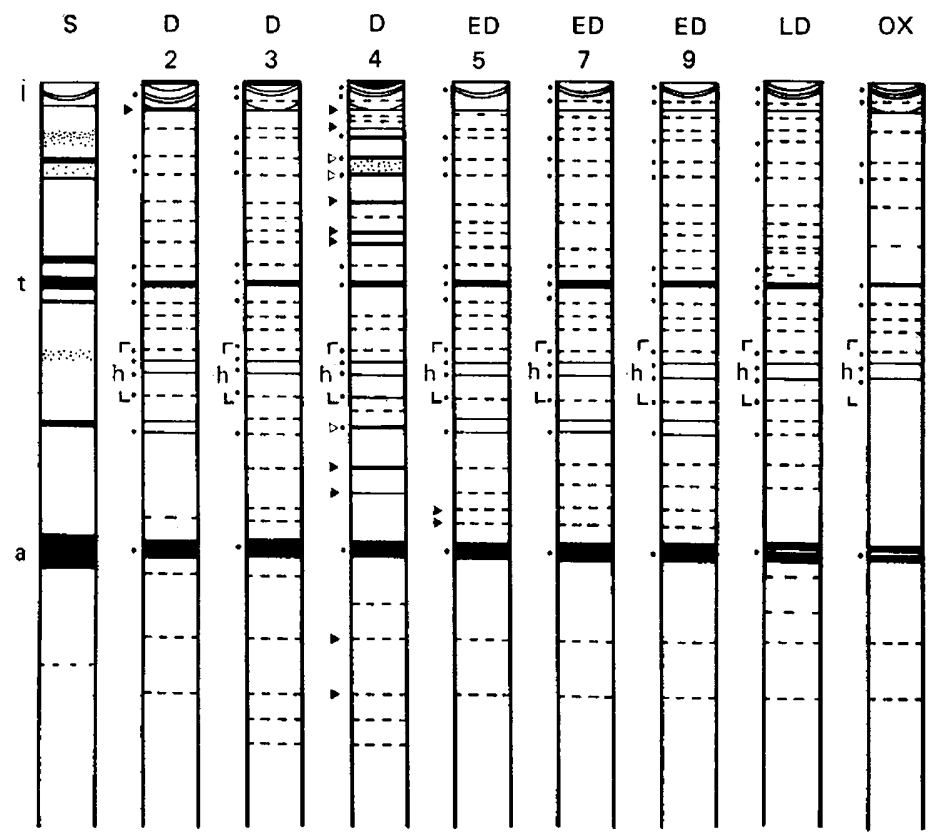

Text-fig. 2. Polyacrylamide gel electrophoresis of mouse uterine flushings during pregnancy, experimental and lactational delayed implantation, and following ovariectomy. $\mathrm{S}=$ mouse plasma; D2 = Day 2 of pregnancy-arrow $=$ non-serum slow $\alpha$-globulin $(R a 0.06) ; \mathrm{D} 3=$ Day 3 of pregnancy; D4 $=$ Day 4 of pregnancy - open arrows $=$ major serum protein at $R a \mathbf{0} \cdot 16,0 \cdot 20,0 \cdot 74$, closed arrows $=$ major non-serum proteins at $R a 0.06,0.10,0.25,0.32,0.34,0.82,0.89,1.19,1.31$; ED $5=$ Day 5 of experimental delayed implantation-closed arrows $=$ non-serum proteins at $R a 0.92,0.95$ which were not present on the day of implantation; ED7 = Day 7 of experimental delayed implantation; ED $9=$ Day 9 of experimental delayed implantation; $\mathrm{LD}=$ lactational delayed implantation; $\mathrm{OX}=$ ovariectomized mice not receiving hormone treatment. $1=$ major serum lipoprotein band; $t=$ transferrin; $h=$ haemoglobin bands; $a=a l b u m i n$. Proteins identified by closed circles are presumed to be of serum origin.

serum bands $(\operatorname{Ra} 0.06,0.10,0.25,0.32,0.34,0.72,1.06,1 \cdot 19,1.32)$ and the appearance of a large quantity of proteinaceous material near the origin of the gels. An increase in the concentration of many serum proteins was also particularly evident at this time, especially in the high molecular weight region of the gels $(R a 0 \cdot 16,0 \cdot 20)$. From 12 to $24 \mathrm{~h}$ after oestradiol administration there was a general reduction in the intensity of all protein bands, followed at $40-48 \mathrm{~h}$ by an increase in the concentration of certain non-serum components. The most dominant of these bands was a slow $\alpha$ globulin $(R a \mathbf{0} \cdot 32)$, while the other major proteins present included slow and fast $\alpha$-globulins $(R a$ $0 \cdot 06,0 \cdot 10,0 \cdot 25,0 \cdot 34,0 \cdot 84,0.89)$ and a maximum of 10 prealbumins $(R a 1 \cdot 06,1 \cdot 09,1 \cdot 16,1 \cdot 19,1 \cdot 24$, $1 \cdot 27,1 \cdot 32,1 \cdot 34,1 \cdot 38,1 \cdot 42$ ). The intensity of these non-serum proteins was greater in those animals receiving the higher dose of oestradiol-17 $\beta$. With the exception of albumin and transferrin, serum proteins were only present in trace amounts $40-48 \mathrm{~h}$ after oestradiol injection (PI. 1, Fig. 1).

Although the uterine response to oestradiol was quantitatively different in pregnant and pseudopregnant mice, the qualitative changes induced by this hormone were similar in both groups of animals (P1. 1, Fig. 2).

\section{Discussion}

The results obtained in this study support observations made on the fur seal (Daniel, 1971), rat (Surani, 1975), roe deer (Aitken, 1974a, b, 1975) and wallaby (Renfree, 1973) in associating embryonic diapause with a lack of proteinaceous material within the uterine lumen. A causal relationship 
between this lack of secretory material and the induction of delayed implantation is suggested by the fact that mouse blastocysts enter a state of diapause in vitro when either whole serum or certain amino acids are omitted from the incubation medium (Gwatkin, 1966a, b; McLaren, 1973). Since the subsequent addition of serum to the medium results in a rapid resumption of blastocyst activity (McLaren, 1973), a causal relationship may also exist between the increase in luminal protein concentration, observed on Day 4 of pregnancy and following oestradiol administration, and blastocyst activation. The features of embryonic activation, whether induced by the addition of serum in vitro or the administration of oestradiol in vivo, certainly appear to be identical. In both instances the blastocyst responds with a marked increase in the rate of DNA and RNA synthesis (Ellem \& Gwatkin, 1968; Prasad, Dass \& Mohla, 1968; Psychoyos \& Bitton-Casimiri, 1969), carbon dioxide production (McLaren \& Menke, 1971) and cell division (Gwatkin \& Meckley, 1966; Bowman \& McLaren, 1970) and the appearance of trophoblastic giant cells (Gwatkin, 1966a, b; Spindle \& Pedersen, 1974).

No evidence could be found in the present study for the existence of inhibitory proteins in the uterine fluids during delayed implantation. Although traces of two fast $\alpha$-globulins $(R a 0.90,0.94)$ were detected during experimental delay and not at the time of implantation, these proteins were absent during lactation and following ovariectomy, despite the fact that both conditions are also associated with embryonic dormancy. However, it is possible that the proposed inhibitor is either not a protein (Psychoyos, 1973) or not resolved on polyacrylamide gels at $\mathrm{pH} 8.9$ because of its charge or molecular weight.

The sudden increase in luminal protein concentration observed on Day 4 of pregnancy appeared to be induced by oestrogen. Plasma oestrogen levels are maximal 1 day before implantation (McCormack \& Greenwald, 1974) and, in the present study, oestradiol-17ß induced a marked rise in the protein content of the uterine fluids when administered during diapause. Examination of the uterine flushings obtained at different times after the injection of oestradiol showed that the response to this hormone was biphasic, involving increases in luminal protein concentration within $12 \mathrm{~h}$ and at 40-48 $\mathrm{h}$ after injection. Qualitatively, the first phase involved the release of high molecular weight proteins into the uterine lumen, some of the most dominant proteins being of serum origin. The presence of serum slow $\alpha$-globulins in the uterine flushings may have been the result of a transient increase in capillary permeability, since a general increase in endometrial vascularity and oedema was observed at this time. Surani (1975) also observed the passage of high molecular weight proteins into the rat uterine lumen 13-20 h after oestradiol injection, and Bergström \& Nilsson (1975) have presented ultrastructural evidence confirming the release of a uterine secretion within $8 \mathrm{~h}$ of oestrogen administration in the mouse. The fact that ultrastructural signs of blastocyst activation are evident within $8 \mathrm{~h}$ of an injection of oestradiol (Nilsson, 1974) suggests that this early phase of uterine secretory activity is responsible for terminating diapause.

The second phase of the uterine response to oestradiol occurred $40-48 \mathrm{~h}$ after the injection of hormone and involved a marked increase in the concentration of certain non-serum proteins. The most prominent of these had an $R a$ value of 0.32 and closely resembled proteins identified in the uterine flushings of women (Wolf \& Mastroianni, 1975; H. Maathius \& R. J. Aitken, unpublished), baboons (Peplow, Breed, Jones \& Eckstein, 1973) and rats, 18-24 h after the administration of oestradiol, maintained in delay with progesterone (Surani, 1975).

The quantitative aspects of the uterine response to oestradiol appeared to depend upon the presence of blastocysts in the uterine lumen. Within $12 \mathrm{~h}$ of oestradiol administration during diapause a quantitative increase in luminal protein concentration was observed in pregnant but not pseudopregnant mice and the increase was apparent several hours before the initiation of blastocyst attachment. It is therefore possible that the activated blastocysts induced a local increase in uterine secretory activity and capillary permeability through the release of, for example, steroids (Perry, Heap \& Amoroso, 1973) or specific proteins (Jones, Heap \& Perry, 1976).

In most eutherian mammals the induction of uterine secretory activity (Urzua, Stambaugh, Flickinger \& Mastroianni, 1970; Arthur \& Daniel, 1972; Knight, Bazer \& Wallace, 1973) and the initiation of implantation (Nalbandov, 1971; Cumming, Baxter \& Lawson, 1974; Murphy \& Mead, 1976) are under the control of progesterone. In the mouse (Yoshinaga \& Adams, 1966) and rat 
(Canivenc \& Laffargue, 1956; Yoshinaga, 1961; Psychoyos, 1973; Surani, 1975), however, these events require the presence of oestrogen as well as progesterone. It may be significant that the other two species for which an oestrogen requirement for implantation has been suggested, the roe deer (Aitken, 1974a, b, 1975) and fur seal (Daniel, 1974), also exhibit the phenomenon of delayed implantation.

Grateful thanks are due to Dr Anne McLaren for her encouragement during this study and to the M.R.C. for financial support.

\section{References}

AItKen, R.J. (1974a) Delayed implantation in the roe deer (Capreolus capreolus). Ph.D. thesis, University of Cambridge.

AITKEN, R.J. (1974b) Delayed implantation in roe deer (Capreolus capreolus). J. Reprod. Fert. 39, 225-233.

AITKEN, R.J. (1975) Ultrastructure of the blastocyst and endometrium of the roe deer (Capreolus capreolus) during delayed implantation. J. Anat. 119, 369-384.

Arthur, A.L. \& Daniel, J.C. (1972) Progesterone regulation of blastokinin production and maintenance of rabbit blastocysts transferred into uteri of castrate recipients. Fert. Steril. 23, 115-122.

Beaton, G.H., Selby, A.E. \& Wright, A.M. (1961) Starch gel electrophoresis of rat serum proteins. J. biol. Chem. 236, 2001-2004.

Bergström, S. \& Nilsson, O. (1975) Embryo-endometrial relationship in the mouse during activation of the blastocyst by oestradiol. J. Reprod. Fert. 44, 117-120.

Bowman, P. \& Mclaren, A. (1970) Cleavage rate of mouse ova in vivo and in vitro. J. Embryol. exp. Morph. 24, 203-207.

Canivenc, R. \& Laffargue, M. (1956) Survie prolongée d'oeufs fécondés non implantés dans l'utérus de rattes castrées et injectées de progesterone. C. r. hebd. Séanc. Acad. Sci., Paris 242, 2857-2860.

Cons, J.M. \& GLAss, L.E. (1963) Electrophoresis of serum proteins and selected enzymes in males, nonpregnant, pregnant and lactating female mice. Proc. Soc. exp. Biol. Med. 113, 893-897.

Cumming, I.A., Baxter, R. \& LAwson, R.A.S. (1974) Steroid hormone requirements for the maintenance of early pregnancy in sheep: a study using ovariectomized adrenalectomized ewes. J. Reprod. Fert. 40, 443-446.

DANIEL, J.C., JR (1971) Growth of the preimplantation embryo of the northern fur seal and its correlation with changes in uterine protein. Devl Biol. 26, 316332.

DANIEL, J.C., JR (1974) Circulating levels of oestradiol$17 \beta$ during early pregnancy in the Alaskan fur seal showing an oestrogen surge preceding implantation. $J$. Reprod. Fert. 37, 425-428.

DAvis, J.B. (1964) Disc electrophoresis. II. Method and application to human serum proteins. Ann. N.Y. Acad. Sci. 121, 404-427.

Ellem, K.A.O. \& Gwatkin, R.B.L. (1968) Patterns of nucleic acid synthesis in the early mouse embryo. Devl Biol. 18, 311-330.

FinN, C.A. \& McLAREN, A. (1967) A study of the early stages of implantation in mice. $J$. Reprod. Fert. 13, 259-267.
Gwatkin, R.B.L. (1966a) Defined media and development of mammalian eggs in vitro. Ann. N.Y. Acad. Sci. 139, 79-90.

GwAtKIN, R.B.L. (1966b) Amino acid requirements for attachment and outgrowth of the mouse blastocyst in vitro. $J$. cell. Physiol. 68, 335-433.

Gwatkin, R.B.L. \& Meckley, D.E. (1966) Chromosomes of the mouse blastocyst following its attachment and outgrowth in vitro. Annls Med. exp. Biol. Fenn. 44, 125-127.

HUMPHREY, K.W. (1967) The induction of implantation in the mouse after ovariectomy. Steroids 10, 591-600.

Jones, L.T., Heap, R.B. \& PerRy, J.S. (1976) Protein synthesis in vitro by pig blastocyst tissue before attachment. J. Reprod. Fert. 47, 129-131.

KNIGHT, J.W., Bazer, F.W. \& Wallace, H.D. (1973) Hormonal regulation of porcine uterine protein secretion. J. Anim. Sci. 36, 546-553.

Lowry, O.H., Rosebrough, N.J., Farr, A.L. \& RANDALL, R.J. (1951) Protein measurements with the Folin-phenol reagent. J. biol. Chem. 193, 265-275.

McCormack, J.T. \& Greenwald, G.S. (1974) Progesterone and oestradiol-17 $\beta$ concentrations in the peripheral plasma during pregnancy in the mouse. J. Endocr. 62, 101-107.

MCLAREN, A. (1968) A study of blastocysts during delay and subsequent implantation in lactating mice. J. Endocr. 42, 453-463.

MCLAREN, A. (1973) Blastocyst activation. In The Regulation of Mammalian Reproduction, pp. 321328. Eds S. J. Segal, R. Crozier, P. A. Corfman \& P. G. Condliffe. Charles C. Thomas, Springfield.

Mclaren, A. \& Menke, T.M. (1971) $\mathrm{CO}_{2}$ output of mouse blastocysts in vitro, in normal pregnancy and in delay. J. Reprod. Fert., Suppl. 14, 23-29.

Menke, T.M. \& MCLaren, A. (1970) Mouse blastocysts grown in vivo and in vitro; carbon dioxide production and trophoblast outgrowth. $J$. Reprod. Fert. 23, 117-127.

Mills, R.M. \& Brinster, R.L. (1967) Oxygen consumption of preimplantation mouse embryos. Expl Cell Res. 47, 337-344.

Morton, J.R. (1966) The multiple electrophoretic bands of mouse haemoglobins. Genet. Res., Camb. 7, 76-85.

MurPhy, B.D. \& MEAD, R.A. (1976) Effects of antibodies to oestrogens on implantation in ferrets. J. Reprod. Fert. 46, 261-263.

Nalbandov, A.V. (1971) Endocrine control of implantation. In The Biology of the Blastocyst, pp. 383-392. Ed. R. J. Blandau. University of Chicago Press, Chicago. 
Nilsson, O. (1974) The morphology of blastocyst implantation. J. Reprod. Fert. 39, 187-194.

Perlow, V., Breed, W.G., Jones, C.M.J. \& Eckstein, M.D. (1973) Studies on uterine flushings in the baboon. I. Method of collection, cellular composition and protein electrophoretic profiles in animals with and without intrauterine contraceptive devices. Am. J. Obstet. Gynec. 116, 771-779.

PerRY, J.S., HEAP, R.B. \& AMORoso, E.C. (1973) Steroid hormone production by pig blastocysts. Nature, Lond. 245, 45-47.

Prasad, M.R.N., Dass, C.M.S. \& Mohla, S. (1968) Action of oestrogen on the blastocyst and uterus in delayed implantation-autoradiographic study. $J$. Reprod. Fert. 16, 97-103.

Psychoyos, A. (1973) Hormonal control of ovo implantation. Vitams Horm. 31, 201-256.

Psychoyos, A. \& Bitton-Casimiri, V. (1969) Caption in vitro d'un précurseur d'acide ribonucléique (ARN) (uridine-5- ${ }^{3} \mathrm{H}$ ) par le blastocyste du rat: différence entre blastocyste normaux et blastocyste en diapause. C. r. hebd. Séanc. Acad. Sci., Paris 268, 188-192.

Renfree, M.B. (1973) Proteins in the uterine secretions of the marsupial, Macropus eugenii. Devl Biol. 32, 41-49.

Renfree, M.B. \& MCLaren, A. (1974) Foetal origin of transferrin in mouse amniotic fluid. Nature, Lond. 252, 159-161.

Spinde,, A.I. \& Pedersen, R.A. (1974) Hatching, attachment and outgrowth of mouse blastocysts in vitro. Fixed nitrogen requirements. J. exp. Zool. 186, 305-318.

SURANI, M.A.H. (1975) Hormonal regulation of proteins in the uterine secretion of ovariectomized rats and the implications for implantation and embryonic diapause. J. Reprod. Fert. 43, 411-417.

Urzua, M.A., Stambaugh, R., Flickinger, G. \& MastrolaNNI, L. (1970) Uterine and oviduct fluid protein patterns in the rabbit before and after ovulation. Fert. Steril. 21, 860-865.

Weitlauf, H.M. (1971) Influence of ovarian hormones on the incorporation of amino acids by blastocysts in vivo. In The Biology of the Blastocyst, pp. 277290. Ed. R. J. Blandau. University of Chicago Press, Chicago.

Wolf, D.P. \& Mastroianni, L. (1975) Protein composition of human uterine fluid. Fert. Steril. 26, 240247.

Woodland, H.R. \& Graham, C.F. (1969) RNA synthesis during early development of the mouse. Nature, Lond. $221,327$.

YoshinAGA, K. (1961) Effect of local application of ovarian hormones on the delay in implantation in lactating rats. J. Reprod. Fert. 2, 35-41.

Yoshinaga, K. \& Adams, C.E. (1966) Delayed implantation in the spayed, progesterone treated adult mouse. J. Reprod. Fert. 12, 593-595.

Received 15 July 1976 